\title{
Perhaps Ned Ludd had a point?
}

\author{
David Smith ${ }^{1}$
}

Accepted: 1 March 2021 / Published online: 23 March 2021

(C) The Author(s), under exclusive licence to Springer-Verlag London Ltd., part of Springer Nature 2021

AI \& Society has covered a great deal of ground in the more than 30 years since we started publication. Our focus has always been on "Human-Centredness". This is not an arbitrary academic problem, to be discussed over coffee in the Senior Common Room, but concerns a real turning point in the evolution of human society and its relationship to the products of human endeavour. As research, development and creative entrepreneurship produce and apply new technologies which bring about massive intended and unintended changes in the ways in which we live, work and even think, the essential question facing us is "cui bono?"-who benefits? and how? This question bears directly onto the ways we live and are governed. As John Dewey argued (Dewey 1950):

“...Democracy has many meanings, but if it has a moral meaning, it is found in resolving that the test of

Editorial note: This volume of AI\&Society covers two special issue themes, 'Ways of Machine Seeing', and 'Bio-art'. Inspired by the John Berger's 1972 BBC documentary series Ways of Seeing, the first theme explores the entanglement of machines and their ways of seeing from a new critical perspectives: How do machines, and, in particular, computational technologies, change the way we see the world? It explores further how Berger's thesis that 'the relation between what we see and what we know is never settled', can be understood in the light of technical developments in machine vision and algorithmic learning, and how the relations between what we see and know are further unsettled. The second theme on "Bio-art' asks: 'What drives Bio-art in the 21st century?', and explores Bio-art as a coalescence of art and sciences, an emerging contemporary artistic practice that uses a wide range of traditional artistic media interwoven with new artistic media that are biological in nature. From a perspective of global challenges, Bio-art communicates thoughts and feelings that involve relationships between the artist, science, public and the biological organism or biological concept. We warmly thank the guest editors of the special issues themes for their scholarly commitment and contribution to the over the horizon ethos of AI\&Society

David Smith

athrylith@email.com

1 AI\&Society, University of South Wales, Cardiff, Wales, UK all political institutions and industrial arrangements shall be the contribution they make to the all-round growth of every member of society."

This question is, in itself, nothing new, and I believe that it is worth reflecting on issues in the history of technology and our relationships to it perhaps gain a better perspective of the present and the future. After all, what is thought of as "technology" exists within a human activity system-a complex environment of human interactions, any component of which is itself indeterminately complex. The actual or potential use of any device in a particular situation may be differently interpreted by various actors. It is crucially important that any debate is well informed, and our community has much to offer in this respect.

During the second half of the eighteenth century, a train of inventions and technical improvements gradually transformed the textile industries of Europe. One important development radically changed the stocking-knitting industry in England. Mainly based in the English midlands, this industry employed expert artisans to produce hosiery. These "stockingers" used specialised machines called stocking frames, originally invented in the sixteenth century. Innovation in the mid-eighteenth century progressively improved the frames to the point that they could be operated by relatively unskilled (and therefore lower paid) workers.

The process of technical improvement accelerated through the early years of the nineteenth century. Mechanisation increased the productivity and lowered the skill requirements of textile production, which was gradually concentrated in large urban production centres. Stockingers, weavers and other skilled textile artisans had soon realised that this was an existential threat to their income and status, and the eponymous Ned Ludd was supposedly responsible for smashing two new stocking frames in 1779, (though there is no clear evidence that he ever actually existed!). The first decade or so of the century saw an outbreak of sabotage and destruction of advanced mechanised textile plant by the so-called "Luddites". At the same time, similar attacks on machines occurred in other industries, for example, the 
destruction of threshing machines in agriculture. Eventually these rebellions were ruthlessly crushed both by the use of troops and by oppressive legislation.

The term "luddite" has subsequently passed into the English to describe irrational hostility to mechanisation and technological development. Many economists speak of the "Luddite Fallacy", arguing that the displacement of labour due to new technologies does not result in long-term structural unemployment. The essential argument is that consequent increased output and decreased cost of production lead to higher demand which requires more and not less labour (but at lower wages). However, this relates to aggregates and ignores the impact on individuals. Whatever macroeconomic theory may assert, the fact remains that the affected textile artisans were utterly impoverished. And not only in the textile industry. In agriculture, manual threshing had provided low-paid but secure winter employment for labourers and their families, and the loss of this income was devastating and long-lasting. Incidentally, a little remarked side effect of the textile revolution in Britain was increased demand pressure on the products of the slave-owning states of the USA, leading to worsening of working conditions of the slaves. In an increasingly globalising world, the impacts of change were no longer local.

Of course, a great deal of technological innovation eventually brought and continues to bring great advantages and a better life to many people. However, this was very seldom immediate, and it could be argued that the lot of most working people, at least in the UK, did not improve materially until well into the twentieth century. The immediate beneficiaries of the new manufacturing economy were a burgeoning middle class. Today it is the middle classes themselves who are threatened by technological change, and it appears to be a tiny minority of extremely wealthy people who derive most benefit. In 2020, there were thought to be about 2000 billionaires in the world, with a combined net worth of $\$ 8$ trillion. At the same time, approximately $10 \%$ of the world population were living on less than $\$ 2$ per day. Even advanced industrial economies were marked by increased labour displacement and insecurity of employment.

So what has this to do with AI \& Society?

In Architect or Bee? (Cooley 1987), one of the foundation texts of the human-centred systems movement, the late Mike Cooley argued that:

"Either we will have a future in which human beings are reduced to a sort of bee-like behaviour, reacting to the systems and equipment specified for them; or we will have a future in which masses of people, conscious of their skills and abilities in both a political and a technical sense, decide that they are going to be the architects of a new form of technological development which will enhance human creativity and mean more freedom of choice and expression rather than less. The truth is, we shall have to make the profound decision as to whether we intend to act as architects or behave like bees."

Which is surely where we come in.

Our journal has a long and honourable history of concern for the complex interactions of human society and advanced computational technologies. Our focus has, of course, changed over the years, from concern with "hard" $\mathrm{AI}$ and its potential consequences to a much broader concern for advanced information technologies of all kinds and their role in the process that Nora and Minc in 1978 called "L'Informatisation de la Société" (Nora and Minc 1977). At the same time, definitions and debate have lost focus among the wider public. There is a tendency for journalists, politicians and others to detach the term "AI" from its specific technical context and to use it instead as a shorthand for "Very hard and clever software engineering that I don't understand", whilst simultaneously endowing the technology with a kind of malicious independent agency.

There is, consequently, inadequate mature discussion of the potential trajectories for the evolution of civil society beyond a general deterministic assumption that, though potentially problematic, "AI" will somehow improve our lot and that an "Information Society" will necessarily be benevolent. We simply cannot afford to assume that this will be so. And we must be very careful about the ways in which we idealise a less than ideal past. When Al Gore spoke in the mid-1990s of "...forging a new Athenian Age of democracy...", it was left to Frances Cairncross (Cairncross 1997) to point out that.

“...Athenian democracy excluded women and slaves, a majority of the population, from the rights of citizenship, and the Athenian assembly was notoriously prone to being hijacked by oligarchs and demagogues..."

Some aspects of this are beginning to acquire a disturbing redolence with the current situation. There is a growing realisation that all is not coming up roses, and the more serious newspapers are beginning to publish critical articles to this effect (O'Connor S 2021). This is a debate in which the AI \& Society community should be recognised leaders.

This journal has a pivotal role to play in developing a mature and informed debate, not only within its own intellectual community, but more widely. We need to balance innovative and erudite scholarly debate with a more aggressive approach to the dissemination of the ideas advanced and developed in these pages over more than 30 years. And we need to pay much more attention not only to the great ethical and theoretical issues, but also to the ways in which actual human lives are impacted by what we think, say and do. It is, perhaps, a simple truism, 
but to design products which can be integrated into a diverse range of normal ways of living, it is necessary to understand their implications for potential life styles and wellbeing. Devices cannot be understood aside from their users and the cultural ambience(s) in which they are used. Recent contributors to AI \& Society have drawn attention to the potential roles of advanced technologies in a variety of real-world contexts, such as artisan crafts (Eglash et al. 2020). We need more well-researched, well-argued work in this direction. And we cannot afford to wait too long. There is a widespread tendency to both overestimate the pace and underestimate the extent of change. We need to act quickly.

The luddites and other machine-breakers were not necessarily opposed to new technology per se, in fact they used it. They were particularly opposed to its use in ways which threatened to annul their skills and to reduce them and their families to near or actual beggary. It is arguable that this is exactly analogous to the situation in some of the modern world's gigantic logistics enterprises.

Perhaps Ned Ludd had a point after all?

Marcus Tullius Cicero was not my favourite Ancient Roman, but he posed a question, though in a different context which we must answer in our own:

"Quo usque tandem abutere Catilina patientia nostra?" Roughly re-stated (with some poetic license) as: "How much longer, AI \& Society, will you try our patience"?

\section{References}

Cairncross F (1997) The death of distance. Orion Press, London

Cooley M (1987) Architect or Bee? The Human Price of Technology. Hogarth Press, UK

Dewey J (1950) Reconstruction in Philosophy. North American Library, New York

Eglash R, Robert L, Bennett A, Robinson K, Lachney M, Babbitt W (2020) Automation for the artisanal economy: enhancing the economic and environmental sustainability of crafting professions with human-machine collaboration. AI \& Soc 35:595-609

Marcus Tullius Cicero. Oratio in Catilinam Secunta Habita ad Populum. Translations abound and Wikipedia is as good a source as any!

Nora S \& Minc A (1977) L'informatisation de la Société. Rapport à M. le Président de la République. Documentation Française, Paris. (English Translation 1980, MIT Press)

See, for example, O'Connor S (2021) Why I was wrong to be optimistic about robots. Financial Times, London. https://www.ft.com/ content/087fce16-3924-4348-8390-235b435c53b2. Accessed 12 Feb 2021

Publisher's Note Springer Nature remains neutral with regard to jurisdictional claims in published maps and institutional affiliations. 